\title{
Czy historia sztuki jest przydatna historykowi?
}

[Michalina D u da, Sławomir J ó ź w i a k, Marcin W i e w i ó r a, Zagraniczne podróże budowniczych (architektów, kamieniarzy, murarzy) i rzeźbiarzy w łacińskiej Europie od X do pierwszej połowy XIV wieku w świetle źródeł pisanych, Wydawnictwo Naukowe Uniwersytetu Mikołaja Kopernika, Toruń 2020, ss. 416.]

Praca trojga autorów jest przedsięwzięciem bardzo ambitnym, właściwie bez precedensu w literaturze naukowej - nie tylko polskiej, ale również znanej mi obcojęzycznej. Wystarczy stwierdzić, że kwestia podróży artystów i związanych z tym „długodystansowych”, międzynarodowych transferów idei, stylów i technik jest kluczowym problemem historii sztuki. Niemal każda praca o sztuce średniowiecznej dotyka tego problemu. Być może z tego właśnie powodu nikt dotychczas nie podjął się napisania tak szeroko zakrojonej syntezy, obejmującej okres dojrzałego średniowiecza (X - połowa XIV w.) i obszar całej Europy łacińskiej (wraz lewantyńskimi państwami krzyżowców). Nie znaczy to, że literatura przedmiotu jest skromna - wręcz przeciwnie, jest ogromna. Autorzy recenzowanej rozprawy wykonali wielką pracę, dokonując krytycznej analizy narosłej literatury, a przede wszystkim źródeł pisanych. Książka jest obszerna, a tekst zaopatrzony został w ponad 1200 przypisów (niektóre są rozbudowane) oraz 40 ilustracji. Tekst podzielony jest na sześć zasadniczych rozdziałów, poprzedzonych Wstępem, a zamkniętych Zakończeniem i bibliografią. Rozdział 1 poświęcony jest analizie pojawiających się w źródłach określeń dotyczących budowniczych-architektów i innych rzemieślników zaangażowanych przy budowach. W rozdziale 2 omówione zostały problemy wzorców, modeli i kopiowania w architekturze średniowiecznej. Rozdział 3 poświęcony jest problematyce importu i, szerzej, pozyskiwania oraz transportu materiałów budowlanych. Rozdział 4, najbardziej rozbudowany (ma podrozdziały i podpodrozdziały), podejmuje kluczowy temat podróży budowniczych, rzemieślników i artystów oraz związanego z tym transferu technologii. Kolejne podrozdziały dotyczą podróży budowniczych z Italii, z Wysp Brytyjskich, z Bizancjum, z Francji (w obecnych granicach, łącznie np. z Lotaryngią) oraz z Niemiec, w podziałach na fazy - odpowiadające z grubsza stuleciom lub połowom stuleci. Osobny rozdział 5 poświęcony jest podróżom architektów nowych zakonów w XII i XIII w. (cystersów, kartuzów, premonstratensów-norbertanów, augustianów-eremitów). Zwraca tu uwagę nieuzasadnione pominięcie najbardziej dynamicznie rozwijających się w tym czasie zakonów franciszkanów i dominikanów. Ostatni rozdział 6. poświęcony jest budowniczym mostów. Jak 
widać, struktura pracy jest klarowna, łączy jednak w sobie różne kryteria: geograficzne z czasowymi i rzeczowymi. W wyniku tego mogą pojawić się wątpliwości lub powtórzenia - np. budowniczy z Francji działający przy budowie niderlandzkiego klasztoru cystersów w XII w. budowanego na wzór macierzystego powinien pojawić się właściwie w rozdziałach 2, 4.4.2. oraz 5. Wyróżnienie w osobnym rozdziale tylko jednego typu budowli (mostów) nie jest zrozumiałe. Oczywiście były to budowle ważne, wymagające niejednokrotnie wielkich nakładów i fachowej wiedzy wykonawców, ale co najmniej równie ważnymi budowlami były zamki, ratusze, nie wspominając o obiektach sakralnych. Zakres chronologiczny wyznaczony został do pewnego stopnia arbitralnie przy pomocy różnych kryteriów. Początek X w. wiąże się z pojawieniem się i „transferem stylu przedromańskiego" - czyli jest to kryterium wyznaczone w oparciu o morfologiczne cechy architektury, nie zaś wypływające z analizy źródeł pisanych. Cezurę końcową (połowa XIV w.) wyznacza skokowy wzrost liczby źródeł pisanych, w związku z czym ich opracowanie przewidziane zostało w odrębnej publikacji (s. 17).

Autorzy śmiało weszli na obszar badań zdominowany dotąd przez historyków sztuki, uznając dotychczasowe wyniki w tym względzie za niewystarczające. Jest to godne uznania i pochwały, gdyż w dążeniu do pełniejszego poznania przeszłości konieczne jest współdziałanie różnych nauk historycznych, mających swoje wypracowane w praktyce badawczej metody i sposoby interpretacji źródeł. Dla historyków sztuki i archeologów podstawowymi źródłami są różne przedmioty materialne (w tym dzieła sztuki), dla historyków - przede wszystkim przekazy pisane. Oczywiście w praktyce wszyscy korzystają także z pozostałych kategorii źródeł, ale ważna jest ich specyficzna hierarchizacja w praktyce badawczej. Dlatego nie budzi zdziwienia, a wręcz oczywiste jest, że Autorzy skupiają się na analizie i interpretacji źródeł pisanych, stosownie do zawodowych specjalności i kompetencji, stwierdzając właśnie na tym polu istotne deficyty w stanie badań.

Autorzy we Wstępie słusznie konstatują wielki przyrost wiedzy na interesujący ich temat, ale z drugiej - stwierdzają, że „pojawiły się pewne niekorzystne zjawiska metodyczne i metodologiczne, które albo w niektórych zakresach ograniczały rozwój badań, albo też, co gorsza, sprowadzały je na fałszywe tory" (s. 8). Przyczynę tego stanu rzeczy upatrują w tym, że „niektórzy uczeni (a to niestety się zdarza) całą wiedzę dotyczącą architektów, kamieniarzy, murarzy, ceglarzy czy rzeźbiarzy czerpią wyłącznie z prowadzonej przez siebie analizy źródeł kultury materialnej, pobieżnie jedynie uwzględniając zachowane przekazy pisane z epoki.” (s. 8). Nie podzielam tak krytycznego stanowiska - nie znam przykładu ostentacyjnego lekceważenia przekazów pisanych w pracach historyków sztuki, choć zdarzają się błędne interpretacje źródeł lub ich nieznajomość. Ale dotyczy to także prac historyków. Książka jest napisana z wyraźnym nastawieniem polemicznym. Autorzy nie tylko zamierzają wypełnić istniejącą lukę w dotychczasowych badaniach, ale także skorygować błędy i obalić utrwalone mity. Ostrze krytyki skierowane jest przede wszystkim w kierunku historyków sztuki: „Dość powiedzieć, że duża część dotychczasowych ustaleń na ten temat opierała się jedynie na przypuszczeniach bądź hipotezach niepopartych mocnymi dowodami, a kolejni uczeni nierzadko latami bezkrytycznie powielali dawne koncepcje” (s. 11). W rozumieniu Autorów „mocnymi dowodami” są jedynie źródła 
pisane: „za podstawę wiedzy o wędrówkach architektów, budowniczych, kamieniarzy, murarzy czy rzeźbiarzy po Europie w rozpatrywanych tu ramach czasowych autorzy uznają źródła pisane z epoki, przede wszystkim narracyjne i dokumentowo-aktowe" (s. 12). Oczywiście wiele koncepcji i hipotez spotykanych w literaturze historycznoartystycznej zasługuje na krytykę, jednak przewijająca się na kartach książki nieufność, czasem granicząca z lekceważeniem, wartości poznawczej analizy porównawczej (np. s. 14: ,na podstawie artystycznego podobieństwa, bądź zwykłych przypuszczeń, a nie twardych dowodów źródłowych”), będącej podstawową metodą historii sztuki, nie jest - moim zdaniem - słuszna. Choć Autorzy słusznie deklarują, że „Niezmiernie ważnym źródłem do badań nad dalekimi wędrówkami architektów, budowniczych, kamieniarzy i rzeźbiarzy w średniowieczu są zachowane w stanie oryginalnym obiekty, w zdecydowanej większości sakralne", natychmiast jednak osłabiają tę deklarację: „Nie można jednak zapominać o licznych, związanych z tą kategorią, ograniczeniach. Przede wszystkim budowli w pierwotnym stanie zachowania przetrwało do współczesności relatywnie mało, a większość z nich ulegała z czasem licznym przebudowom i przekształceniom" (s. 13). To stwierdzenie można sformułować mocniej: nie ma ani jednej średniowiecznej budowli zachowanej do naszych czasów w stanie pierwotnym, gdyż wszystkie uległy w ciągu wieków przekształceniom. Nie zmienia to jednak w istotny sposób ich wartości źródłowej. Historia sztuki wypracowała szereg metod służących „rozwarstwianiu” budowli czyli określania ich historycznych przekształceń. Analogicznie, jak w badaniach historycznych krytyka źródeł pozwala niejednokrotnie wyróżnić ich różne „warstwy”, np. fragmenty wcześniejszych tekstów zawarte w tekstach późniejszych. Twierdzenie, że źródła pisane dostarczają „twardych dowodów” (s. 14), jest moim zdaniem nieuzasadnione. Po pierwsze dlatego, że - ściśle rzecz ujmując - o dowodach możemy mówić jedynie w matematyce lub logice. W naukach empirycznych mamy do czynienia jedynie z argumentami. Po drugie - źródła pisane (jak każde inne) powinny zawsze podlegać dyskusji i interpretacji. Omawiana książka w końcu przecież tego właśnie dotyczy. Źródła pisane mogą również zawierać informacje niezgodne ze stanem faktycznym (czyli mogą wprowadzać w błąd w przypadku niewłaściwej lektury). Spektakularnym przykładem z naszej dziedziny jest monumentalna inskrypcja na fryzie rzymskiego Panteonu: M[arcus] AGRIPPA L[uci] F[ilius] $\mathrm{CO}[\mathrm{n}] \mathrm{S}[\mathrm{ul}] \mathrm{TERTIUM} \mathrm{FECIT.} \mathrm{To} \mathrm{jednak} \mathrm{na} \mathrm{podstawie} \mathrm{innych} \mathrm{przesła-}$ nek niż źródła pisane można było ustalić, że budowla ta nie powstała za czasów Agryppy i Augusta, lecz za Trajana i Hadriana, a inskrypcję, ze względu na pamięć o pierwotnym fundatorze, ,przepisano” na wzniesionej de novo świątyni. Na s. 127 Autorzy przytaczają stwierdzenie Kosmasa, że św. Wacław kazał wznieść na grodzie praskim kościół św. Wita ad similitudinem Romanae ecclesiae rotundam, słusznie interpretując wzmiankowany pierwowzór jako rzymski Panteon. Swoje wnioskowanie prowadzą dalej: „Przekaz Kosmasa, o ile uznać jego wiarygodność, niesie ze sobą jeszcze inny dodatkowy ciężar gatunkowy. Jeśli bowiem przy wznoszeniu kamiennej świątyni na Hradczanach w pierwszej ćwierci X w. miano by za modelowy przyjąć jeden z bardziej spektakularnych rzymskich kościołów, to jest niemal pewne, iż do takiego zadania musiano sprowadzić architektów i budowniczych z zewnątrz" (s. 127). Otóż sprawa nie jest taka prosta. Kosmas pisał około 200 lat po tych wydarzeniach, 
co każe z dużą ostrożnością podchodzić do tej informacji. Z pewnością wynika z niej jedynie to, że Kosmas chciał ją swoim czytelnikom zakomunikować. Jednak nie wiemy, skąd on o sprawie wiedział?, czy znał prawdę?, czy istniała wiarygodna tradycja? A może sam ją „wymyślił”, aby popisać się erudycją, interpretując dostojny zabytek poprzez wskazanie starożytnego pierwowzoru? A może konfabulował jego informator? Wniosek wyprowadzony przez Autorów z zapiski Kosmasa jest poprawny, choć oparty na fałszywej przesłance (czyli zgodnie z zasadami logiki - rozumowanie poprawne). Rzeczywiście - powinniśmy uznać jako bardzo prawdopodobne, że do takiego zadania musiano sprowadzić budowniczych z zewnątrz, ale nie dlatego, że kronikarz wskazał Panteon jako pierwowzór, ale dlatego, że kościół św. Wita był jedną z najwcześniejszych budowli murowanych w Czechach - i tam po prostu nie było odpowiednich fachowców. Dlatego nie jest słuszna gołosłowna krytyka tezy czeskiej badaczki: „Wbrew jasnej wymowie przekazu Kosmasa, Anežka Merhautová doszukiwała się jakichś wzorcowych dla praskiej rotund w basenie Morza Adriatyckiego - -. A przecież kronikarz wyraźnie wskazywał na Rzym" (s. 127, przyp. 115). W odróżnieniu od tekstów, mury nie kłamią. Owszem, zazwyczaj ich wymowa nie jest jednoznaczna, ale z tekstami jest przecież podobnie. Otóż praska rotunda oprócz kolistego planu nie ma wiele wspólnego z Panteonem. W Rzymie w X w. nie budowano rotund podobnych do Panteonu ani podobnych do praskiej rotundy, a nad Adriatykiem - owszem.

Oczywisty fakt, że wiele budowli powstałych w średniowieczu nie przetrwało, a te, które przetrwały, są przekształcone mniej lub bardziej w późniejszych czasach, nie może być argumentem uzasadniającym pomijanie lub lekceważenie ich analizy. Analogiczną sytuację mamy w przypadku źródeł pisanych - wiele tekstów napisanych w średniowieczu nie przetrwało, a te, które przetrwały, często są dostępne jedynie „Z drugiej ręki” (w formie odpisów, cytatów, edycji etc.). Oczywiście poszczególni badacze - zgodnie ze swoją specjalizacją - skupiają się na wybranych aspektach, nie powinni jednak tracić z pola widzenia istnienia innych perspektyw i nie absolutyzować własnego punktu widzenia. Wydaje się to truizmem, szczególnie wobec powszechnych dążeń do „interdyscyplinarności”. Tymczasem Autorzy omawianej pracy nie tylko krytykują poszczególne tezy historyków sztuki (co jest całkowicie uprawnione), ale wielokrotnie dają wyraz poglądowi, że konstatacje historyków sztuki są jedynie subiektywnymi dywagacjami ,na podstawie domniemanych podobieństw". Zdaje się tu pobrzmiewać starożytne, anachroniczne, ale, jak się okazuje, ciągle pokutujące rozróżnienie na litterati (rozumiejący słowo pisane) i laici sive idiotae, dla których obrazy zastępują słowo pisane (pictura laicorum scriptura). Dobitnie i klarownie wyraził takie stanowisko wybitny mediewista Ernst Robert Curtius w swojej monumentalnej pracy o literaturze średniowiecznej: „literatura jest nośnikiem idei, a sztuka nim nie jest. - - Tak zwana »nauka o sztuce« jest w sytuacji łatwiejszej. Ma ona bowiem do czynienia z obrazami - oraz z przeźroczami. Tu nie ma nic do zrozumienia. Aby pojąć poezję Pindara, trzeba na to ciężkiego wysiłku umysłowego - aby zaś zrozumieć Partenon, nie trzeba go wcale. Ta sama relacja występuje między Dantem a katedrą itd." Autorzy omawianej pracy domyślają się przyczyn niezadowalającego stanu $\mathrm{w}$,zwykłej niewiedzy o istnieniu średniowiecznych źródeł pisanych --, a nierzadko przeszkodą jest również nieznajomość języka 
przekazów z epoki (łacina, języki narodowe). Tymczasem tylko pełna wiedza na temat wszystkich istniejących źródeł oraz ich gruntowna krytyczna analiza daje szansę na wyciągnięcie wniosków w miarę możliwości oddających bardziej rzeczywiste realia badanego okresu" (s. 8). Może jest to konstatacja słuszna w niektórych przypadkach, natomiast na pewno nie jest słuszna jako generalizacja. Po pierwsze - wśród historyków sztuki całkiem sporo jest umiejących czytać i pisać, o czym świadczy choćby fakt, że podstawowe korpusy źródeł wykorzystywane przez Autorów są efektem pracy historyków sztuki. Po drugie (i ważniejsze) - postulat ,pełnej wiedzy na temat wszystkich istniejących źródeł” jest utopijny. Jeśli ktoś twierdzi, że posiadł „pełną wiedzę na temat wszystkich istniejących źródeł”, niech pierwszy rzuci kamieniem. Postęp w naukach historycznych dokonuje się także przez odkrywanie nowych źródeł i reinterpretację już wcześniej znanych (znowu truizm). Nieuprawnionym, uogólniającym zarzutem jest również stwierdzenie: „Historycy sztuki doszukują się zapożyczeń najczęściej na podstawie porównywania układów przestrzennych i detali architektonicznych zachowanych do dzisiaj obiektów" (s. 133). Owszem, historycy sztuki czynią tak również, podobnie jak historycy doszukujący się zapożyczeń porównując zachowane teksty. Stopień podobieństwa (analogii) oczywiście zawsze podlega dyskusji. Konstatowanie podobieństwa jest z natury rzeczy obciążone pewną dozą subiektywizmu (naukę tworzą ludzie niebędący istotami wszechwiedzącymi), jednak sama metoda jest jak najbardziej naukowa. Podobnie zresztą czynią historycy - na przykład paleografowie rozróżniający „ręce” poszczególnych skrybów na podstawie cech formalnych pisma czy też badacze dokonujący atrybucji i datowania anonimowych tekstów na podstawie stwierdzenia analogii z innymi tekstami. Nie trzeba dodawać, że są to z natury rzeczy ustalenia hipotetyczne, ale jednak zupełnie uprawnione. Autorzy recenzowanej rozprawy twierdzą np., że teza o pobieraniu nauki rzemiosła architektonicznego przez pierwszego architekta (magister lapicida, rector fabrice ipsius ecclesie) gotyckiej katedry w Kolonii, mistrza Gerharda (Gerardus), na budowach katedr w północnej Francji „pozostaje jedynie w sferze domysłów” (s. 73). Nie ma jednak innego sposobu wytłumaczenia bardzo daleko idącej zbieżności form architektury (także szczegółów technicznych) tej katedry i np. katedr w Amiens czy Beauvais, niż założenie, że projektant gruntownie zaznajomił się z nimi in situ. Natomiast „w sferze domysłów” musi pozostać, czy magister Gerardus był autorem projektu katedry kolońskiej, czy „tylko” kierownikiem budowy. Dyskutowana kwestia nie polega jedynie na analogii ogólnie rozumianych cech „stylu gotyckiego”. Pojęcie stylu w historii sztuki jest bardzo wieloznaczne: od stylu konkretnego artysty, poprzez styl regionalny, styl jakiejś grupy aż do bardzo dużego uogólnienia - stylu epoki. W każdym razie jest mowa o pewnej grupie dzieł charakteryzujących się określonymi cechami morfologicznymi. „Styl gotycki” rozumiany jako styl epoki jest po prostu nazwą-etykietą i nie mówi właściwie nic poza tym, że opatrzony taką etykietą obiekt powstał prawdopodobnie pomiędzy połową XII a połową XVI w. Oczywiście opatrzenie tą etykietą dwóch obiektów nie jest stwierdzeniem ich historycznej relacji (choć jej też nie wyklucza).

Dla historyka sztuki dość zdumiewająca jest hipoteza czy też uogólniający wniosek, tłumaczący stosunkowo niewielką, zdaniem Autorów, uchwytność w źródłach pisanych budowniczych niemieckich (s. 315, powtórzony w Zakończeniu - s. 380): 
„Bardzo ogólnie i mocno upraszczając, można by to próbować tłumaczyć faktem, że na obszarach niemieckojęzycznych nie odkryto żadnego nowatorskiego modelu czy stylu budownictwa (odnosi się to zarówno do okresu romanizmu, jak i gotyku), stąd też fachowcy specjalizujący się w profesjach budowlanych raczej tam przybywali, niż stamtąd wyjeżdżali”. Jest to nie tylko uproszczenie, ale po prostu nieprawda. Trudno wdawać się w ramach recenzji w prezentowanie szerokiego wykładu historii architektury, jednak nie sposób powstrzymać się od komentarza, że tylko nieznajomość rzeczy może być źródłem takich kategorycznych stwierdzeń. Otóż nazwy stylów („romański”, ,gotycki”) są terminami zbiorczymi i wieloznacznymi, mogą oznaczać bardzo zróżnicowane zbiory dzieł i cech formalnych, precyzyjniej należałoby mówić o wielu stylach romańskich i gotyckich. Na terenach niemieckojęzycznych co najmniej od czasów karolińskich do końca średniowiecza powstawały oryginalne i wybitne w skali powszechnej dzieła architektury, zaś recepcja „wpływów” zewnętrznych była częstokroć impulsem dla nowatorskich kreacji. Wielka liczba budowli średniowiecznych zachowanych do dziś na tym obszarze świadczy też o znacznej liczebności zawodów budowlanych - oczywiście z uwzględnieniem nierównomiernej dystrybucji w czasie i przestrzeni, co oczywiście nie wyklucza również dalekosiężnych wędrówek i przybyszów zagranicznych.

Autorzy zdają się żywić przekonanie, że jedyne, co można wywnioskować z analizy struktury wizualnej dzieła sztuki, jest jego zaklasyfikowanie do tych najogólniejszych zbiorów - stylu romańskiego lub gotyckiego. Dobrą ilustracją sposobu, w jaki Autorzy polemizują z tezami historyków sztuki, jest fragment tekstu ze s. 135: „Po lekturze artykułu P. Kurmanna z całą pewnością można stwierdzić jedynie to, że obie analizowane przez niego katedry [w Reims i Kolonii - J.J.] były wznoszone w stylu gotyckim. Reszta to tylko przypuszczenia tego autora, oparte na wrażeniach, a nie na dowodach. W każdym razie z porównania detali architektonicznych (jedyna podstawa wnioskowania) był $\mathrm{w}$ stanie stwierdzić tylko tyle, że niektóre $\mathrm{z}$ nich wykazywały duże podobieństwo a inne nie. - - Oczywiście wszystkie te koncepcje to jedynie przypuszczenia formułowane na podstawie porównań detali architektonicznych zachowanych do dzisiaj obiektów". Można zadać pytanie, czy Autorzy rzeczywiście uważają, że tezy jednego z najwybitniejszych znawców architektury XIII w. są tak niedorzeczne, czy może ich nie rozumieją (lub nie chcą rozumieć)? Istota metod stosowanych $\mathrm{w}$ historii sztuki w gruncie rzeczy nie różni się od tej w historii ,tout court” - dokonuje się krytyki źródeł, ich analizy i interpretacji, a na tej podstawie tworzy się uogólnienia. Nikomu chyba nie przyszłoby do głowy, aby czynić zarzut historykom, że dokonując porównań detali, czyli fragmentów zachowanych tekstów, i formułując na tej podstawie wnioski, mogą stwierdzić jedynie tyle, że zostały napisane po łacinie, niektóre $\mathrm{z}$ tych fragmentów są podobne, inne nie. Niedawno Tomasz Jasiński, posługując się „odwiecznymi metodami” - analizą porównawczą tekstów - wykazał z wielkim prawdopodobieństwem, że Gall Anonim był Wenecjaninem. Badacz ten nie dysponował innymi źródłami niż jego poprzednicy, jednak wnikliwiej je analizował i porównywał systematycznie z licznymi innymi tekstami, co było znacznie ułatwione dzięki nowym środkom technicznym - digitalizacji tekstów źródłowych umożliwiającej ich szybsze porównywanie. Również w historii sztuki metoda analizy porównawczej staje się coraz bardziej precyzyjna 
dzięki coraz bogatszym bazom danych dostępnych powszechnie, dzięki technice komputerowej i cyfrowej fotografii. Historia sztuki posługuje się od dawna metodami, które po części są dla niej specyficzne, a po części wspólne z innymi dyscyplinami historycznymi. Autorzy pracy zarzucają również historykom sztuki skłonność do tworzenia mitów historiograficznych. Trudno zaprzeczyć - historia każdej dyscypliny naukowej jest w znacznym stopniu historią obalonych, sfalsyfikowanych teorii, które możemy tak nazwać. Również pod tym względem historia sztuki jest nieodrodną częścią rodziny nauk historycznych i nie jestem pewien, czy zaszczyt dzierżenia „palmy pierwszeństwa” (s. 351), przyznany przez Autorów historykom sztuki, jest w pełni zasłużony.

Praca napisana jest językiem jasnym i precyzyjnym, choć z polemicznym zacięciem (co oczywiście nie jest wadą). Natomiast można odnieść wrażenie, że niekiedy brak jest właściwego zrozumienia problematyki historycznoartystycznej - nie wiadomo, czy jest to skutek, czy przyczyna tak negatywnej oceny większości przytaczanych prac historyków sztuki. Chyba na skutek nieporozumienia przypisano Richardowi Krautheimerowi głoszenie zupełnie fałszywej, wręcz absurdalnej tezy. Badacz ten, jakoby „porównując dość przypadkowo wybrane świątynie na planie centralnym (okrągłe, oktogonalne), wzniesione w okresie między IX a XII w., i sądząc zarazem - co wcale nie jest takie oczywiste - że wszystkie one były wzorowane na jerozolimskiej rotundzie Anastasis, doszedł do wniosku, że proces reprodukcji (kopiowania) w średniowiecznej architekturze podporządkowany był innym imperatywom niż prosta zgodność formalna" (s. 100). Krautheimer nie głosił, jakoby wszystkie centralne kościoły w okresie IX-XII w. były wzorowane na jerozolimskiej rotundzie, natomiast całkiem słusznie stwierdził, że średniowieczne „kopie” Anastasis są w wielu aspektach zupełnie niepodobne do jerozolimskiego wzorca. Potwierdza to zresztą przegląd dokonany przez Autorów (s. 85-100) poświadczonych źródłowo „kopii”. Różnią się też one znacznie między sobą, zatem należałoby raczej mówić o „cytatach” lub ,parafrazach”. Analogicznie w przypadku tekstu, którego sens (czyli istotne z określonego punktu widzenia treści) może być oddany nie tylko w dosłownej kopii, ale też w streszczeniu, cytacie, parafrazie, zaś aspekty z danego punktu widzenia nieistotne mogą być pominięte. Dla niektórych fundatorów mogła na przykład być nieistotna liczba kolumn, a istotny centralny plan lub jedynie liczba filarów. Dla skryby streszczającego dokument nieistotna może być liczba sylab lub wersów czy też kształt liter. Wskazywane w źródłach pisanych wzorce, którym poświęcono rozdział 2 (Anastasis, Świątynia Jerozolimska, kaplica Karola Wielkiego w Akwizgranie, kościół św. Piotra w Rzymie) były swego rodzaju archetypami, które naśladowano właśnie w ten „wybiórczy” sposób - żadna ze średniowiecznych „kopii” tych budowli nie replikowała wszystkich cech, gdyż było to niepotrzebne i niemożliwe. Przytaczany (s. 90-93) przykład opata Winona wysłanego przez biskupa Meinwerka z Paderborn do Jerozolimy dla zaznajomienia się z Anastasis jest bardzo wymowny - kościoły wzniesione w Westfalii na podstawie informacji opata były dziełem budowniczych miejscowych. Aby przenieść wzór architektoniczny, wcale nie było trzeba sprowadzać budowniczych z danego miejsca. To zleceniodawca decydował o wielkości i zasadniczym programie (pierwowzorze) budowli. W kompetencjach budowniczych były kwestie techniczne i rozwiązania artystyczne wyrażające się 
np. w szczegółach ornamentalnych i innych detalach. Stąd tak duża waga przywiązywana do ich analizy przez historyków sztuki, która budzi sprzeciw Autorów. Reasumując: z faktu, że dana budowla została wzniesiona według przekazów źródłowych np. ad instar kaplicy akwizgrańskiej, żadną miarą nie da się wywnioskować, że wzniesiona została przez budowniczych z tego miasta. Tak więc rozdział 2 (Wzorzec architektoniczny i jego kopiowanie), choć ciekawy i bogaty w informacje, nie dotyczy wcale tytułowego zagadnienia - wędrówek budowniczych.

Autorzy czynią zarzut jednej z francuskich badaczek (przyp. 125 na s. 130), że ,ppopadła w tej kwestii [wzorów kolejnych kościołów w Cluny - dopisek J.J.] w wyraźne sprzeczności, twierdząc, iż modelem dla Cluny III była Bazylika Świętego Piotra w Rzymie, podczas gdy parę stron dalej skonstatowała, iż burgundzka świątynia była prototypem zupełnie nowatorskiej architektury“. Jest to jeden z przykładów niezrozumienia argumentacji typowej dla historyków sztuki (bo przecież nie złej woli). Nie ma tu żadnej sprzeczności - po prostu pewne cechy kościoła Cluny III nawiązują do dostojnego rzymskiego wzorca, inne zaś są oryginalne i nowatorskie. Tak samo nie są sprzeczne twierdzenia, że np. Wincenty Kadłubek nawiązywał do Cycerona czy Boecjusza, oraz że był pisarzem oryginalnym. W innym miejscu (s. 304) Autorzy polemizują z hipotezą Petera Kurmanna, próbującego wyjaśnić zaskakująco wierne nawiązanie w rzeźbie katedry w Burgos do rzeźb w Amiens i Reims poprzez hipotetyczne założenie zastosowania plastycznych modeli (czyli znanych w późniejszych czasach tzw. bozzetti). Zdaniem Autorów jest ona „niepoparta żadnymi twardymi dowodami źródłowymi”, prostszym rozwiązaniem byłoby bowiem według nich założenie obecności w Burgos francuskich rzeźbiarzy. Nie jest to sprzeczne z hipotezą Kurmanna, który też taką możliwość zakładał, jednak nie tłumaczy to stopnia i szczegółowości konstatowanych zbieżności. Inaczej mówiąc: samo bycie francuskim rzeźbiarzem, nawet utalentowanym, nie wystarczyło, aby tak wiernie i szczegółowo ,zreprodukować” konkretne francuskie rzeźby w dalekiej Kastylii. Autorzy stwierdzają dalej: „Wyniki nowszych badań nie potwierdzają, by katedra w Burgos była ściśle wzorowana na swojej imienniczce z Francji. Jedyne wyraźne podobieństwa między tymi świątyniami są widoczne w przypadku triforiów, rzeźby portali, niektórych kolumn, filarów i sklepień“ (s. 305). Otóż, jak już pisałem, w średniowiecznej architekturze nie ma „kopii“ w sensie dosłownym (reprodukcji wszystkich cech oryginału). Nikt zresztą nie twierdził, że katedra w Burgos jest „ściśle wzorowana” na Bourges, natomiast przywoływany w przyp. 533 ze s. 305 Henrik Karge przekonująco wykazał, że ta właśnie francuska katedra była dla hiszpańskiej najważniejszym źródłem rozwiązań architektonicznych. W odniesieniu do katedry w Famaguście na Cyprze Autorzy stwierdzają: „Są jednak mocne przesłanki przemawiające za tym, że zarówno architekt, jak i przynajmniej niektórzy budowniczowie-rzemieślnicy mogli pochodzić z Francji, skoro biskup Baldwin potrzebne środki finansowe pozyskał od arcybiskupa Langres (na północny wschód od Dijon), Gerarda“ (s. 311). Pochodzenie pieniędzy przeznaczonych na finansowanie budowy nie jest jednak jakąkolwiek wskazówką na rzecz pochodzenia rzemieślników z tej samej okolicy, choć też go oczywiście nie wyklucza - w tym przypadku to forma architektoniczna przemawia za rzecz północnofrancuskiej genezy. Zauważmy, że znaczący wkład na finansowanie kościoła Cluny III wniósł król Kastylii, a katedra 
w Kolonii była finansowana między innymi z pieniędzy angielskich, co nie znalazło jakiegokolwiek odzwierciedlenia w formach architektonicznych.

W omawianej pracy pojawiają się także - nieliczne co prawda - postacie budowniczych z terenów polskich: Jacobus lapicida, quondam magister operis z Trzebnicy (s. 347) oraz Theodoricus magister operis z Koronowa (s. 349). Intrygujące jest pominięcie wspomnianego również przy okazji budowy klasztoru w Trzebnicy w 1204 r. Dalemira nazwanego cementarius, choć przywoływana jest praca Morelowskiego obszernie omawiająca tę postać, tym bardziej, że sam termin cementarius jest w recenzowanej książce przedmiotem wnikliwych dociekań na wielu przykładach (s. 65-82). Szczególnie dziwny wydaje się brak wzmianki na temat Simona z Wąchocka i Koprzywnicy, choć problem pochodzenia budowniczych małopolskich klasztorów cysterskich został także omówiony (s. 344-346). Postać tego rzekomego mnicha i budowniczego była przedmiotem wieloletniej ożywionej debaty w polskiej historii sztuki. Autorzy przywołują zresztą publikację, gdzie ta dyskusja została podsumowana (E. Łużyniecka, R. Kunkel, Z. Świechowski, Architektura opactw cysterskich. Małopolskie filie Morimond, Wrocław 2008), zaś Simon (konwers-budowniczy w San Galgano, identyfikowany dawniej przez niektórych badaczy z „naszym” Simonem) jest wzmiankowany na s. 342 omawianej książki. Autorzy jednak nie podjęli tego problemu w swoich wywodach, a szkoda, gdyż byłaby to znakomita okazja do kolejnego wskazania „mitotwórstwa” w historii sztuki. Nie znajdziemy też w omawianej pracy informacji o Radovanie - twórcy wspaniałego portalu katedry w dalmackim Trogirze, który uwiecznił się na swoim dziele kwiecistą sygnaturą w 1240 r. Choć jego imię jest ewidentnie słowiańskie, cechy stylistyczne wykonanego przez niego portalu wskazują wyraźnie na włoską proweniencję. Oczywiście trudno oczekiwać, nawet w tej stosunkowo obszernej pracy, informacji o wszystkich uchwytnych źródłowo artystach z tego okresu, jednak ten przykład jest godny uwagi, gdyż może świadczyć o „wyjeździe na naukę” do obcych krajów. Te „podróże praktykantów”, choć często zakładane w historii sztuki jako rzecz oczywista, okazują się nie mieć potwierdzenia $\mathrm{w}$ świetle źródeł pisanych z epoki.

Postępując zgodnie z przyjętymi założeniami (że jedynie źródła pisane dostarczają ,twardych dowodów”), Autorzy zaprzeczyli wielu utrwalonym w historiografii artystycznej poglądom - np. temu o znaczącym udziale budowniczych i rzeźbiarzy z północnej Italii w rozpowszechnianiu form rzeźbiarskich i architektonicznych w środkowej i północnej Europie. Natomiast dużą mobilność i ekspansywność przypisali budowniczym z terenów obecnej Francji. Niezależnie od przekonań recenzenta co do trafności tych tez (z pierwszą się nie zgadzam, drugą uznaję za trafną), prezentowane $\mathrm{w}$ pracy stwierdzenia są oryginalne, uargumentowane i zaprezentowane $\mathrm{z}$ polemicznym temperamentem. $Z$ pewnością pobudzają do dyskusji. Ta sama przeszła rzeczywistość oglądana z różnych perspektyw, za pośrednictwem różnych mediów, wygląda różnie. Te perspektywy nie muszą być rozłączne, mogą się uzupełniać. Choćbyśmy nie wiadomo jak precyzyjnie analizowali formy architektoniczne, nie mamy raczej szans, aby na ich podstawie stwierdzić, jakim językiem mówił ich wykonawca. Natomiast takie szanse (nie „dowody”) mamy w przypadku dysponowania źródłami pisanymi. Z lakonicznych zazwyczaj wzmianek o budowniczych rzadko kiedy da się jednak coś istotnego wywnioskować odnośnie interpretacji samych dzieł. Na przykład to, 
że znamy imię Jakuba, kierownika budowy (magister operis) w Trzebnicy, w żaden sposób nie przybliża nas do odpowiedzi na jedno z podstawowych pytań: dlaczego jego dzieło jest właśnie takie? Radykalna jednostronność metodyczna - skupienie uwagi na zapiskach jako jedynym uprawnionym źródle wiedzy o przeszłości - daje obraz różny od tego, jaki pojawia się przy uwzględnieniu innych kategorii źródeł. Nie jestem przekonany, czy bardziej prawdziwy. Oczywiście z punktu widzenia metodologicznej klarowności powinniśmy wiedzieć, co i skąd wiemy, jednak zdrowy rozsądek podpowiada, że nie wszystko zostało w średniowieczu utrwalone na piśmie, a jeszcze mniej z tych zapisków przetrwało. Pewien wybitny historyk mówił (żartując oczywiście), że przez dwa pierwsze wieki dziejów Polski w zasadzie nie było Polek (a jeśli jakimś trafem się pojawiały, to je natychmiast wysyłano za granicę), gdyż nie ma o nich prawie żadnych informacji w źródłach pisanych.

W swoim negatywnym nastawieniu do pracy historyków sztuki Autorzy omawianej książki nie są jednak (na szczęście) całkowicie konsekwentni, gdyż opierają się w końcu przede wszystkim na rezultatach ich dociekań. Uznają także niektóre ustalenia dokonane na podstawie analizy form - o ile ,pasują” do ich tezy. Na przykład: pomnik nagrobny królowej Izabeli w Cosenzy uznają za bezsporne dzieło rzeźbiarza francuskiego, choć nie jest to stwierdzenie na podstawie źródeł pisanych, a ,jedynie” na podstawie porównawczej analizy form - stwierdzeniu bliskich analogii do współczesnych dzieł paryskich (s. 285). Uznają również (niepopartą źródłami pisanymi) zależność kształtu kościoła w Losne od wzoru Vignory: „W jedenastowiecznych źródłach pisanych nie ma dowodów pozwalających jednoznacznie stwierdzić, że w tym przypadku [chodzi o kościoły w Vignory i Losne - J.J.] przy budowie późniejszej świątyni wzorowano się na wcześniejszej, a jednak analiza architektoniczna (a takie możliwości pojawiają się niezmiernie rzadko) bezspornie potwierdza ten fakt" (s. 84). Natomiast w wielu innych przypadkach wskazywane analogie kwitowane są lekceważąco, jako ,subiektywne wrażenia”.

Zapewne liczni historycy sztuki, mimo krytycznych uwag i zarzutów, częstokroć niesprawiedliwych, formułowanych wobec ich dyscypliny i metod, z zainteresowaniem i z pożytkiem skorzystają z tej pracy. Krytyka - czasem surowa - jest ,paliwem” napędzającym naukę. Niezależnie od polemicznego temperamentu, jaki prezentują Autorzy, dokonali oni wielkiej pracy, analizując i komentując źródła najróżniejszych kategorii, z różnych miejsc i czasów. Ogrom zebranego materiału jest dla czytelnika niekiedy trudny do „ogarnięcia”, gdyż poszczególne partie tekstu składają się z dłuższych lub krótszych akapitów, poświęconych analizie poszczególnych wzmianek źródłowych, a związek pomiędzy kolejnymi fragmentami nie jest oczywisty (nie jest to w każdym razie konsekwentny układ chronologiczny). Istotnym mankamentem jest w tej sytuacji brak indeksów - w przypadku nowego wydania należy koniecznie to uzupełnić. Kilka uwag odnośnie terminologii. Może nie tyle błędem terminologicznym, ale stylistyczną niezręcznością jest stosowanie terminu ,sala kapitulna“ (który jest kalką z języka francuskiego lub niemieckiego) zamiast polskiego „kapitularza“ (s. 84, 346). To samo można powiedzieć o „deambulatorium“ (s. 94) - po polsku to jest obejście lub ambit.

Autorzy oparli się przede wszystkim na wyborach tekstów źródłowych opracowanych przez historyków sztuki, przede wszystkim monumentalne dzieła Otto 
Lehmanna-Brockhausa (Schriftquellen zur Kunstgeschichte des 11. und 12. Jahrhunderts für Deutschland, Lothringen und Italien, Berlin 1938; Lateinische Schriftquellen zur Kunst in England, Wales und Schottland vom Jahre 901 bis zum Jahre 1307, München 1955-1960), Victora Morteta i Paula Deschampsa (Recueil de textes relatifs à l'histoire de l'architecture en France au Moyen Âge, XIe à XIIIe siecles, Paris 1911-1929, wyd. 2: 1995) oraz Martina Warnkego (Bau und Überbau. Soziologie der mittelalterlichen Architektur nach den Schriftquellen, Frankfurt a.M. 1984), a także wielu innych publikacjach - obszerna bibliografia (selektywna) liczy 15 stron. Wykazali się wielką erudycją, docierając do olbrzymiej liczby publikacji monograficznych, szczegółowych i przyczynkarskich. Przy tak szeroko zakrojonej tematyce oczywiście nie jest możliwe uwzględnienie pełnej literatury przedmiotu i nie byłoby to nawet sensowne (wbrew postulatowi Autorów o konieczności uzyskania „pełnej wiedzy”). Musi natomiast budzić zdziwienie nieuwzględnienie kilku publikacji podstawowych dla tego tematu, m.in.: P. Frankl, The Gothic. Literary Sources and Interpretations through Eight Centuries, Princeton 1960; W. Vroom, Financing cathedral building in the Middle Ages. The Generosity of the Faithful, Amsterdam 2010; M. Untermann, Forma ordinis. Die mittelalterliche Baukunst der Zisterzienser, Berlin-München 2001. W znacznym stopniu ciągle niezastąpiona jest monografia Douglasa Knoopa i Gwilyma P. Jonesa, The Medieval Mason. An Economic History of English Stone Building in the Later Middle Ages and Early Modern Times, New York 1967 (wyd. 1: 1933). Dla problematyki średniowiecznych sygnatur podstawowe znaczenie mają prace Alberta Dietla, w tym czterotomowa synteza: Sprache der Signatur. Die mittelalterliche Künstlerinschriften Italiens, München 2009. Choć Autorzy przywołują kilka prac Petera C. Claussena, pomijają jego inne, co najmniej równie ważne publikacje: Nachrichten von den Antipoden oder der mittelalterliche Künstler über sich selbst, w: Der Künstler über sich in seinem Werk, Weinheim 1992, s. 19-54, oraz: Magistri doctissimi romani. Die römischen Marmorkünstler des Mittelalters, Stuttgart 1987. Podobnie w przypadku Günthera Bindinga, wśród przywoływanych prac brak jego publikacji szczególnie ważnych dla poruszanej problematyki: Baubetrieb im Mittealter, Darmstadt 2013 (wyd. 1: 1993) oraz Der früh- und hochmittelalterliche Bauherr als sapiens architectus, Darmstadt 1998. Specyficznym rodzajem źródeł pisanych jest literatura piękna. W literaturze strarofrancuskiej tematy architektoniczne mają istotne znaczenie, co znakomicie pokazał Jacek Kowalski, Rymowane zamki. Tematy architektoniczne w literaturze starofrancuskiej drugiej połowy XII wieku, Warszawa 2001.

Wnikliwa, systematyczna kwerenda w polskich źródłach ujawniłaby z pewnością więcej wzmianek o budowniczych i budowlach w średniowiecznej Polsce. Wielu historyków sztuki (piszący te słowa na pewno) z wdzięcznością przyjęłoby korpus tekstów źródłowych dotyczących ziem polskich, podobny do tych wydanych przez Morteta i Deschampsa czy Lehmanna-Brockhausa. W tym przypadku wypada sformułować postulat dla przyszłych badaczy.

W niniejszej recenzji, sprowokowany polemiczną wobec historii sztuki wymową tej publikacji, skupiłem się na aspektach dyskusyjnych względem tez w niej zawartych a apologetycznych względem własnej dyscypliny (historii sztuki). Na koniec jednak chciałbym jeszcze raz podkreślić wagę podjętych przez Autorów badań i wielki 
nakład ich pracy. Czytelnicy uzyskali wgląd w niezwykle ciekawą problematykę sytuującą się na pogranicznym obszarze. Książkę z pożytkiem dla siebie z pewnością przeczytają mediewiści różnych specjalności a być może również uznają ją za godną podjęcia poważnej dyskusji. 